\title{
Voter Turnouts in Presidential Elections in Ghana: A Political Economy Analysis Using District-Level Data
}

\author{
Kwabena Asomanin Anaman ${ }^{1}$, \& Gbensuglo Alidu Bukari ${ }^{2}$ \\ ${ }^{1}$ Professor, Department of Agricultural Economics and Agribusiness, College of Basic and Applied Sciences, \\ University of Ghana, Legon, Accra. \\ ${ }^{2}$ Post-doctoral Research Fellow, Merian Institute for Advanced Studies in Africa, University of Ghana, Legon, Accra. \\ Correspondence: Kwabena Asomanin Anaman, Department of Agricultural Economics and Agribusiness, College of \\ Basic and Applied Sciences, University of Ghana, Legon, Accra, Ghana.
}

Received: October 5, 2020

doi:10.11114/aef.v8i1.5083
Accepted: November 12, $2020 \quad$ Available online: November 20, 2020

URL: https://doi.org/10.11114/aef.v8i1.5083

\begin{abstract}
During the Fourth Republican electioneering era in Ghana, starting in November 1992, presidential elections are conducted every four years. The 2000 and 2012 elections closely coincided with the national population censuses of 2000 and 2010, respectively. We constructed meso-level models, based on the concept of "average district voter", to analyse factors influencing voter turnout rates. The results of the analysis indicated that voting was a normal good based on the estimated inelastic price and income elasticities of demand for this good. As expected, the cost of voting incurred by an individual negatively influenced turnout. The other significant negative factors influencing turnout rates included increasing male/female sex ratio (gender), increasing age-based dependency ratio (poverty burden), and disability.
\end{abstract}

Keywords: consumer demand, Ghana, social exclusion, turnout, voter participation, unpriced goods

\section{Introduction}

\subsection{Background}

Ghana, with an earlier name of Gold Coast, is situated in the western part of Africa. It achieved its independence from Great Britain on 6 March 1957 after the Gold Coast had been a quasi-colony of Great Britain for 113 years, since 6 March 1844, when 17 traditional states signed a defence treaty with the British government. The treaty allowed the signatories to adequately defend themselves against attacks from other traditional African states, and agents of other European powers, during the last phase of the Trans-Atlantic Slave Trade, which ended in North America in 1865 (Ellis, 1894).

In 1874, the British government unilaterally changed the 1844 security-treaty arrangement into a colonial one. The 1874 colonial arrangement included the original 17 traditional states which signed the 1844 treaty, plus traditional states in the current southern Volta region (such as Anlo, Keta, Peki and Tongu), Eastern and Western regions. These other traditional states were added to the 1844 entity through various security agreements. The Asante kingdom was later incorporated into the colony after it was conquered in 1896. The bulk of the five northern regions was included in the Gold Coast colony in 1902 after the British government signed friendship treaties with several principal chiefs. The Trans-Volta Togoland became part of the Gold Coast in 1956, after a United Nations-organized referendum (Amenumey, 1968).

On independence day, 6 March 1957, the Gold Coast was renamed Ghana by the Convention People's Party (CPP), led by Dr. Kwame Nkrumah, which led the country to independence. Ghana became a Republic on 1 July 1960, after a referendum organized on 27 April 1960. The CPP won the concurrent presidential election with $89.1 \%$ of the valid votes. The other party which contested this election was the United Party formed in 1958. The United Party was a union of several ethnic-based and religious-oriented parties formed to meet the requirement of a new law introduced in Parliament in 1958 for political parties to have a national character and representation to reduce ethnic-based and sectarian politics. 


\subsection{The Problem Statement}

While there is international interest in African elections, there is limited published material on the determinants of voter turnouts of African mass elections. The limited literature on voter turnouts in Africa also tends to focus on structuralist variables, such as ethnicity, gender, and locality. The issue of the individual's demand for voting as an economic service supplied by the State has not been adequately covered in published African electoral studies. Voting in mass elections, as argued by Morris Silver in 1973, is a consumer good, which provides an end in itself, involving costs to access this good. These costs influence voter participation. It is the citizens' approval of elected politicians in fairly-conducted elections that gives legitimacy to these politicians to manage State institutions on their behalf for a period of time.

While Ghana is sometimes hailed internationally for three relatively peaceful transfers of political power from one party to another in the Fourth Republican era, in 2001, 2009 and 2017, there are underlying tensions that have threatened to truncate the democratic process, which are related to issues involving voter turnouts and electoral registers. In the December 2008 presidential election, the democratic system almost broke down over disputes over election results with a core issue being the unusually high voter turnout rates in some of the strongholds of the two main political parties, the National Democratic Congress (NDC) and New Patriotic Party (NPP), which appeared to affect the outcomes of the election. The behind-the-scenes negotiations of the National Peace Council led by the Roman Catholic Archbishop of Cape Coast, Cardinal Peter Kodwo Appiah Turkson (currently working at the Vatican) brought the disputes under control, allowing a peaceful transition on 7 January 2009. Further, the outcome of the December 2012 election was decided at the Supreme Court (SC) after an eight-month legal battle between NDC and NPP. This legal battle was won by the NDC on 28 August 2013 by a split decision of the nine SC Justices on several issues including voter turnouts.

As shown in Table 1, a feature of Fourth Republican elections in Ghana has been the fluctuating turnout rates measured as the number of votes cast divided by the number of registered voters. The official turnout rate which was only $50.16 \%$ in the November 1992 election jumped to $78.20 \%$ in the December 1996 election and then went down to $61.74 \%$ during the first round election on 7 December 2000. The turnout rate then sharply increased to $85.12 \%$ in the December 2004 election only to drop down to $71.00 \%$ in the first round December 2008 election. The turnout rate went up again in 2012 and dropped sharply in 2016. The voter turnout rate exhibits the classic econometrics textbook example of negative autocorrelation characterized by sharp and sudden mood swings.

Ghanaian electoral registers are consistently bloated, with registered voters, supposedly aged 18 years and over, being much more than people aged over 14 in many districts (Bukari, 2017, pp. 414-423). A major source of bloating of electoral registers is the registration of under-age citizens by the two main parties, NDC and NPP, with the objective of maximizing their chances of winning power, achieved through the abuse of an identification system, whereby two or more people certify that a particular person is a Ghanaian citizen, 18 years or above.

During the 2020 electoral registration, the Electoral Commission of Ghana (ECG) registered 1,375,048 citizens, aged 18 and 19 , constituting $8.1 \%$ of the total registered voters (ECG, 2020). Citizens between 15 to 24 years constituted $32.5 \%$ and $34.1 \%$ of citizens aged 15 and over, in 2000 and 2010, respectively (GSS, 2013). The $8.1 \%$ proportion attributed to citizens aged 18 and 19 years in the new 2020 register suggested that the proportion of people aged 15 to 24 in the current citizen population would be over $40 \%$ of all citizens aged 15 and over. A $40 \%$ proportion was highly unlikely given the historical trends. This indicated that the 2020 register was bloated with under-age people, like the previous registers, compiled in the Fourth Republic, with many citizens claiming to be 18 or 19 years, below the legal voting age of 18 .

The main objective of this study was to establish the factors influencing voter participation rates in Ghana using the unique set of data available from the 2000 and 2012 national elections and the 2000 and 2010 censuses. The rest of this paper is organized as follows: the literature review is discussed next. This is followed by the methods used for the study. The results of the analysis are then presented followed by the conclusions, recommendations and a list of references. 
Table 1. Registered voters, votes cast, valid votes, spoiled votes, and the official turnout rates in seven presidential elections in Ghana from 1992 to 2016

\begin{tabular}{|l|c|c|c|c|c|c|}
\hline Year & $\begin{array}{l}\text { Total number } \\
\text { of registered } \\
\text { people }\end{array}$ & Total votes cast & $\begin{array}{l}\text { Total valid votes } \\
\text { cast }\end{array}$ & $\begin{array}{l}\text { Total spoiled } \\
\text { ballots }\end{array}$ & $\begin{array}{l}\text { Percentage } \\
\text { turnout }\end{array}$ & $\begin{array}{l}\text { Percentage of total } \\
\text { votes due to spoiled } \\
\text { ballots }\end{array}$ \\
\hline 2016 & $15,712,499$ & $10,880,999$ & $10,713,734$ & 167,349 & 69.25 & 1.54 \\
\hline 2012 & $14,158,890$ & $11,246,982$ & $10,995,262$ & 251,720 & 79.43 & 2.24 \\
\hline 2008 (first round) & $12,532,758$ & $8,897,937$ & $8,691,941$ & 205,996 & 71.00 & 2.32 \\
\hline 2004 & $10,354,970$ & $8,813,908$ & $8,625,785$ & 188,123 & 85.12 & 2.13 \\
\hline 2000 (first round) & $10,698,652$ & $6,605,084$ & $6,500,870$ & 104,214 & 61.74 & 1.58 \\
\hline 1996 & $9,279,605$ & $7,256,872$ & $7,145,764$ & 111,108 & 78.20 & 1.53 \\
\hline 1992 & $8,229,902$ & $4,127,876$ & $3,978,065$ & 149,811 & 50.16 & 3.63 \\
\hline
\end{tabular}

Source: Electoral Commission of Ghana (ECG), Various Reports

Notes: By mid-August 2020, the ECG had registered 16,963,306 people for the 2020 national election (ECG, 2020).

\section{Literature Review}

\subsection{Overview of Political Economy and Governance in the Fourth Republican Era}

The Fourth Republican era in Ghana started on 7 January 1993. The national governance is structured around the Executive President who has considerable powers including the right to appoint all Mayors and Chief Executives of the 260 districts of the country. The country has nine broad ethnic groups. The Guans are the first ethnic group to settle in Ghana. They, and their earlier relatives, arrived in the country at least 30,000 years ago, and are the original landowners of Ghana. The Guans number around 1.2 million, about $4 \%$ of Ghana's population. The other eight broad ethnic groups are (A) Akan, (B) Dangme/Ga, (C) Ewe, (D) Grusi, (E) Gurma, (F) Mande, (G) Mole-Dagbani, and (H) All others. These eight groups started to settle in Ghana from the $11^{\text {th }}$ Century AD, about 1,000 years ago (Davidson, 1972; Ellis, 1894).

Overall, Ghana has a total of 89 individual tribes coming from the nine broad ethnic groups (GSS, 2017). The nine dominant tribes, using population shares from the 2000 Census, are (1) Asante (14.8\%), (2) Ewe (12.7\%), (3) Fante (9.9\%), (4) Bono (4.6\%), (5) Dangme (4.3\%), (6) Dagomba (4.3\%), (7) Ga (3.4\%), (8) Akyem (3.4\%), and (9) Akuapem (2.9\%) (GSS, 2013). These nine dominant tribes constitute about $60 \%$ of the citizen population. From structuralism political economy perspective, the elites of the nine big tribes extensively dominate Ghana's political governance and State institutional landscape, including government-linked international appointments, State contracts, national civic awards, national symbols such as persons featured on Ghanaian currency notes, and choreographed national unity events.

The remaining $40 \%$ of the citizen population belong to 80 small tribes with an average share of population of $0.5 \%$ each. Members of these 80 small tribes are marginalized in State governance and institutional structures (Anaman and Bukari, 2019a, 2019b). This marginalization includes the very low numbers of administrative districts allocated to areas inhabited by small tribes, which have the required numbers of 75,000 people, for the creation of new districts but have been consistently denied district status in the Fourth Republican era. Yet, many new districts were created for areas inhabited by members of big tribes, which did not have the required numbers of people, in 2004, 2008, 2012 and $2017 .{ }^{1}$

Based on the seventh round of the Ghana Living Standards Survey (GLSS) completed in 2017, the average poverty rate of Ghana was 23.4\% (GSS, 2018). Members of small tribes account for almost three out of four (73.2\%) of poor Ghanaians. Further, virtually all the two-and-half million Ghanaians, who do not have enough food to eat and are unable to get the minimum daily 2,900 calories of energy for biological sustenance, referring to the extremely poor proportion of $8.2 \%$, come from these small tribes, revealed by an analysis of the GLSS7 data using the population of 31 million.

The average per capita gross domestic product (GDP) of Ghana was 2,212 United States dollars (US\$) in 2019 based on a total GDP of US\$66,984 million (GSS, 2020). Ghana regained its lower-middle-income status in 2009, defined as per capita income of at least US\$1,000. It was classified as a lower-middle-income country in 1961. This was just before the 1962 to 1965 period of major collapse of world cocoa prices, and the 1962-63 severe El Nino weather event. At that time, Ghana was the leading producer of cocoa and accounted for $37.5 \%$ of world's production. Both economic shocks pushed the country just below middle-income status over 1962-1965 period (Anaman, 2018). The economy rapidly deteriorated from 1966 to 1983 mainly due to political instability arising from five successful and many attempted military coups. 
With the new political stability, continuous economic growth resumed in 1984 with positive growth recorded over the 36-year period from 1984 to 2019. This growth was partly induced by large-scale environmental destruction. Anaman and Agyei-Sasu (2014) established that 36\% of the GDP of Ghana from 1993 to 2012 was accounted for by environmental capital inputs, linked to environmental destruction, captured by GDP valuation, which involves double counting of environmental activities. This growth has also been associated with widening income inequality (GSS, 2008, 2014, 2018). The income Gini coefficient of Ghana increased from 41.9 in 2006 to 42.3 in 2013, and then to 43.0 in 2017 (GSS, 2018, p. 23). The burden of the income inequality has been increasingly laid on members of very small tribes, revealed through an analysis of per capita household economic welfare, using GLSS data compiled in 2006, 2013 and $2017 .^{2}$

The current economic structure of Ghana is seriously weakened by four factors which threaten the sustainability of democratic governance in the country. The first factor is the sharp increase of the country's foreign debts. These debts went up from 2.1 billion United States dollars (US\$) in December 2006, after US\$4.2 billion debts cancellation by international development agencies, to US\$23.9 billion in June 2020, over 1,200\% increase in thirteen-and-half years. The country's foreign debts increased by US $\$ 7.5$ billion from December 2016 to June 2020, over a period of three years and six months (Government of Ghana, 2020). According to the Bank of Ghana (2020), total government debts were 263 billion Ghana cedis (GHS) or (US $\$ 46.3$ billion) at the end of July 2020, equivalent to $68.3 \%$ of the rebased GDP, an increase of GHS141 billion in three years and seven months, from the level at the end of December 2016 (GHS 122 billion). The International Monetary Fund forecast Ghana's total debts to GDP ratio to be $76.7 \%$ by the end of 2020 .

Second, the increasing levels of government debts are linked to declining government capital expenditure/GDP ratio. This ratio reached a level of $1.8 \%$ in 2019, the lowest in 63 years of independence. Recent government overseas borrowings have been mainly used for debt repayments and government consumption activities. By the end of December 2019, and before the occurrence of the coronavirus Covid-19 pandemic, the fiscal position of the government was very weak (Institute for Fiscal Studies ((IFS), 2020). As shown in Figure 1, the years, 2000, 2019 and 2020 were the three years that the total revenues and grants were virtually used for debts repayments and employee compensation (IFS, 2020).

Third, large amounts of debts incurred by State institutions have been used for many projects which are abandoned when a new political party takes control of government. These include almost completed clinics, hospitals, schools, and many partially completed road works which are left to be destroyed by the rains during the rainy seasons (Anaman and Bukari, 2019a). The Ghanaian physical landscape is littered with numerous factories, and other built structures, worth billions of US dollars, mostly financed with foreign loans, which have been abandoned since the first military coup on 24 February $1966 .{ }^{3}$ The need to revive abandoned factories and built structures is a major theme of a new political party, the Ghana Union Movement, one of the 12 political parties, contesting the 7 December 2020 presidential election. Its television station and website provide images of many abandoned structures from 1966 onwards.

Fourth, democratic political transitions in Ghana are increasingly associated with governmental actions which destroy businesses such as banks, factories, finance companies, radio and television stations, and schools of indigenous elites, who are perceived to be opponents of the ruling party (Anaman, 2016), leading to the losses of thousands of jobs, and ill-health of these elites, and early deaths of many workers formerly employed by their businesses.

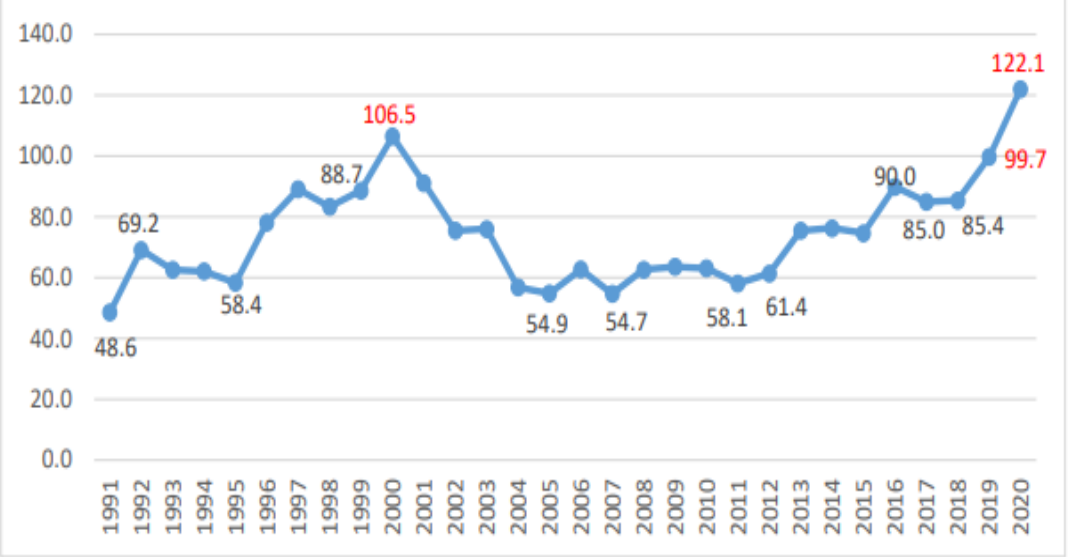

Figure 1. Illustration of the sum of the government debt payments and compensation of employees as a percentage of total revenues and grants received by the government over the 30-year period from 1991 to 2020

Source: Institute for Fiscal Studies, Accra (2020) 


\subsection{Theories of Electoral Participation}

This review of theories of electoral participation is guided by a political-economy understanding of the linkages of the three major super-structures that drive a society: (1) Markets, (2) Community and the (3) State. From an individual, market-based point of view, a modern democracy rests on an assumption that all adult citizens are eligible to vote in elections. This universal adult suffrage emerged more recently, one hundred years ago, in 1920, in the United States, and a little earlier in New Zealand, in 1893, when women were allowed to vote. The optimal level of individual citizens' participation for a democracy has been debated by scholars. Bachrach (1967) indicates that governments function best when elites, who are knowledgeable about political affairs, are in charge. Therefore people with little knowledge about politics should be discouraged from voting. However, many scholars disagree with this notion and suggest that equal right of all citizens to participate in the elections is required for proper functioning of democracies (Norris, 2002).

The American political economist, Anthony Downs was the first scholar to formulate the economically-rational voter participation model based on his doctorate thesis produced in 1957 at the Stanford University entitled "An Economic Theory of Democracy". Downs argues that the decision of an individual to vote in an election rests on his/her calculation of the benefits and costs of voting. With the vote from an individual having little impact on the outcome of an election, and the fact that voting itself involves some costs such as transportation charges and the time-related costs, the decision to vote could not be justified on the direct benefits alone. There have been extensions of the rational choice theory, especially with regards to the benefits accruing to the individual for voting (for a review, see Muller (2014, pp. 33-40)).

The second super-structure of society is Community which is a concept used in the political economy literature to refer to non-governmental organizations and non-State actors, often working in groups, which shape individual decisions, such as voter choices. The Community also includes groups established through blood ties such as extended families, clan lineages and chieftaincy structures, which are common in Ghana, and primarily act through voluntary and semi-voluntary actions and structures. Socialization engendered through community structures such as churches, clubs and family-based associations could encourage individual participation in elections. Ethnic groups could also influence individual participation in elections, through the mobilization efforts by their political class elites (Anaman and Bukari, 2019a).

Another theory, linked to the concept of Community, that explains voter participation, is the theory of mobilization suggested by Rosenstone and Hansen (1996). They argue that a citizen is not an island by himself or herself and should not be viewed in isolation in terms of policy-driven programmes. A citizen has social networks which involve friends, extended family members, neighbours, co-workers, and others. These social networks could influence the individual's decision to participate in elections. Political parties are created for an objective to mobilize potential voters and encourage them to cast votes for the parties in order for them to win power. Political parties therefore develop voter mobilization capital with the aim of using that capital to achieve the goal of convincing individuals to vote for their parties (Anaman and Bukari, 2019a). The individual's decision to vote then depends also on the activities of political parties.

The third superstructure of society is the State and government. The government is the group of people who controls the State apparatus and also often controls the finances used to run the three branches of the State (Executive, Legislature and Judiciary). Voting is done by an individual citizen, in mass elections, which often involves a secret ballot system. It is the role of the State, through the government, to provide voting as a public service for individual citizens. Hence, as suggested by Norris (2002), it is the duty of the State to provide the required infrastructure such as adequate number of polling stations and good security, paying special attention to the needs of the disabled and marginalized, so that citizens can vote with ease and comfort. McAllister (1992) argues that high voter participation is also dependent on the State undertaking civic education activities to encourage citizens to participate in voting.

\subsection{Overview of Empirical Works on the Determinants of Voter Participation and Turnout}

Following the work of Downs, Silver (1973) analysed voting as a consumer good. He argued that voting in national elections was an end by itself (consumer good), and certainly not a means; the latter would define voting as a producer good. He further argued that voting was not a "free" good but involved costs including transportation and time-related costs. The individual votes because it provides a psychic income to him/her even though his/her vote has negligible impact on the electoral outcome. What this psychic income, gained from voting entails, has been the focus of works by several scholars (for example, refer to Geys, 2006; Lacy and Christenson, 2016).

The factors affecting voter turnouts have been researched extensively. Solijonov (2016), in reviewing the literature on the subject, identifies these factors to include the population size, perceptions of the importance of campaign issues, campaign expenditures, electoral systems and voting arrangements. Individual factors such as the age, sex, employment status affect voter participation. The positive impact on turnout from increased information on radio and television 
about candidates in elections was established by Settle and Abrams (1976). For specific individual characteristics of voters, the apathy of young people has been indicated in a large cross-country study (IDEA, 2006). Gender has also been identified as an important individual characteristic with the general observation across many countries that women vote relatively less as a proportion than men (Solinojov, 2016). However, for the United States, the Centre for American Women and Politics (2019) indicated that since 1980, in every presidential election, the proportion of eligible male adults who voted had been less than the proportion of eligible adult females who voted.

The effect of the disability status of voters on their participation in elections was analysed by Schur (2017). She established that there was no significant difference in turnout rates in the 2016 presidential election in the United States between employed people with disabilities and employed people without disabilities. However, she showed that voter turnout was generally lower among citizens with disabilities; inaccessible polling places increased the costs of voting to disabled people impeding turnouts. The issue of an individual turning up to vote, but deliberately spoiling his/her ballot paper, possibly due to dissatisfaction with the governance systems, is found in Ghanaian elections, where such ballot papers are included in the spoiled papers category. These ballot papers are identified by the voter marking each space assigned to every candidate. Hayden (2010) provided a reasoning behind such behaviour by his detailed analysis of voter abstention.

There is also a growing level of studies on electoral corruption across the world (refer to Vicente, 2014; Nwankwo, 2018). Mares and Zhu (2015) analysed issues related to electoral corruption arguing that this phenomenon was multidimensional in nature. Electoral corruption includes vote buying by politicians, the distribution of benefits to individuals around the time of elections by politicians and their aides, and electoral intimidation of citizens to vote in a particular way. Electoral intimidation could be exercised by private actors, such as firms with loyalties to particular political parties, who may threaten to terminate the appointments of their workers if they do not vote for selected political parties. Vote buying involves the transfer of material gifts from one entity to another to encourage an individual to vote in a particular way.

\subsection{Theoretical Formulation of Voter Participation Used in this Study}

The rational choice of voting developed by Downs (1957) indicates that an individual will vote in an election if the expected benefit from his/her voting exceeds his/her costs involved in voting. In 1968, Riker and Ordeshook suggested a calculus of voting based on the Downs' hypothesis. The voting calculus developed by Riker and Ordeshook is expressed in Equation 1 as follows:

$$
\mathrm{R}=(\mathrm{B} * \mathrm{P})-\mathrm{C}+\mathrm{D}
$$

Equation 1

Where $\mathrm{R}$ is the expected net return from voting by the individual; $\mathrm{B}$ is the personal benefit that the voter gets from his preferred candidate winning the election; $\mathrm{P}$ is the probability of the individual's vote resulting in his/her preferred candidate winning the election; $\mathrm{C}$ is the cost to the individual incurred in voting in the election; and $\mathrm{D}$ is the personal benefits accruing to the individual for voting, which go beyond the benefits arising when his/her preferred candidate wins the election.

In this study, we use an adaption of the calculus of Riker and Ordeshook. We argue that voting is essentially a non-market good that is supplied by the State and demanded by eligible adult citizens. The State provides the resources including the venues and arrangements for individuals to vote. This non-market good is used (when the individual votes) or not used (when the individual refuses to vote or is unable to vote). Hence, the economic valuation of the benefits of voter participation could be captured by the concept of the total economic value, commonly used in resource and environmental economics, for valuing unpriced and non-market goods and services.

Therefore Equation 1 can be recast as Equation 2 as follows:

$$
\mathrm{R}=\left(\mathrm{B}_{1} * \mathrm{P}\right)+\left(\mathrm{B}_{2} * \mathrm{P}\right)+\mathrm{B}_{3}+\mathrm{B}_{4}-\mathrm{C}
$$

Equation 2

Where $\mathrm{B}_{1}$ is the direct use value of voting related to the voter getting actual benefit from his/her preferred candidate winning the election; $\mathrm{B}_{2}$ is the option use value related to the potential benefit that the individual voter gets in his/her future lifetime for his/her preferred candidate winning the election; benefits are not necessarily received within the short-term period of his/her elected term; this situation may arise when the elected public official progresses through the career ranks, and the individual voter gets benefits from this official at much later time; $\mathrm{B}_{3}$ is the vicarious use value of voting arising from the individual voter getting benefits from his/her voting through the creation of benefits for other individuals or society in general; $\mathrm{B}_{4}$ is the bequest use value of voting arising from the voter getting benefits from his/her voting due to the benefits created from his/her action for future generations of human beings. Hence $\mathrm{B}_{3}$ and $\mathrm{B}_{4}$ 
are independent of the benefits, $\mathrm{B}_{1}$ and $\mathrm{B}_{2}$, gained from the voter's preferred candidate winning the election. Using the total economic value for assigning benefits to voter participation allows for the inter-temporal nature of benefits, beyond the direct benefits, gained by the individual for voting, within the short-term period, to be analysed.

The essence of the neoclassical economics theory of voter participation is that an individual votes in an election when the expected net return is positive. Per the arguments set forth in Equations 1 and 2, voter turnout is determined by individual voter characteristics such as his/her distance-related costs and time costs in participating in voting, proxied by distance to polling stations and availability of polling stations, within a given geographical area. Disability status increases the individual cost of voting and hence could affect the turnout rate. Other characteristics, such as income, which could provide better information to the individual about the various benefits of voting, increase the likelihood of the individual voting. Higher income and wealth statuses could result in a greater appreciation for the vicarious use and bequest use values of voting $\left(\mathrm{B}_{3}\right.$ and $\left.\mathrm{B}_{4}\right)$.

We build district-based models of voter participation using the neoclassical economics paradigm. Equation 3 indicates some variables that affect voter turnout linked to individual characteristics.

Voter turnout (quantity) $=\mathrm{f}$ (costs of voting, per capita income, disability status, employment status, formal educational attainment)

Equation 3

Figure 2 describes the neoclassical economics description of voter turnout versus costs of voting relationship. The cost of voting (price) is on the vertical axis. The number of voters (quantity) is on the horizontal axis, as is the norm in economics textbooks. The initial supply curve is labelled $S_{1}$ and it indicates the number of voters that the ECG can handle on a polling day, based on its capacity to supply the voting service. The demand of voting service by citizens depends on the costs of voting to the individual. The cost of voting in this study is proxied by the travel costs to the individual district voter, based on the land area of the district divided by the number of polling stations. As the cost of voting rises, individuals will demand less of the voting service supplied by the ECG and will show up less to vote at polling stations. As the cost of voting declines, more individuals show up to vote.

The supply curve of EC can shift to the left from $S_{1}$ to $S_{2}$, for example, if the ECG suddenly reduces the number of polling stations on polling day, based on internal challenges, such as those posed by either artificial or natural hazards, (for example severe rainfall over extended periods of time in a district, or outbreaks of diseases or violent incidents). With the cost of voting shifting from $\mathrm{OC}_{1}$ to $\mathrm{OC}_{2}$, the equilibrium number of voters is reduced from $\mathrm{OV}_{1}$ to $\mathrm{OV}_{2}$. The price elasticity of demand for voting is the percentage change in the number of voters given one percent change in costs of voting. Similarly, the income elasticity of demand is the percentage change in the number of voters given one percent change in per capita income. The dependent variable, the number of votes, is reflected in this study as the voter turnout ratio, which measures the intensity of people participating in the electoral process.

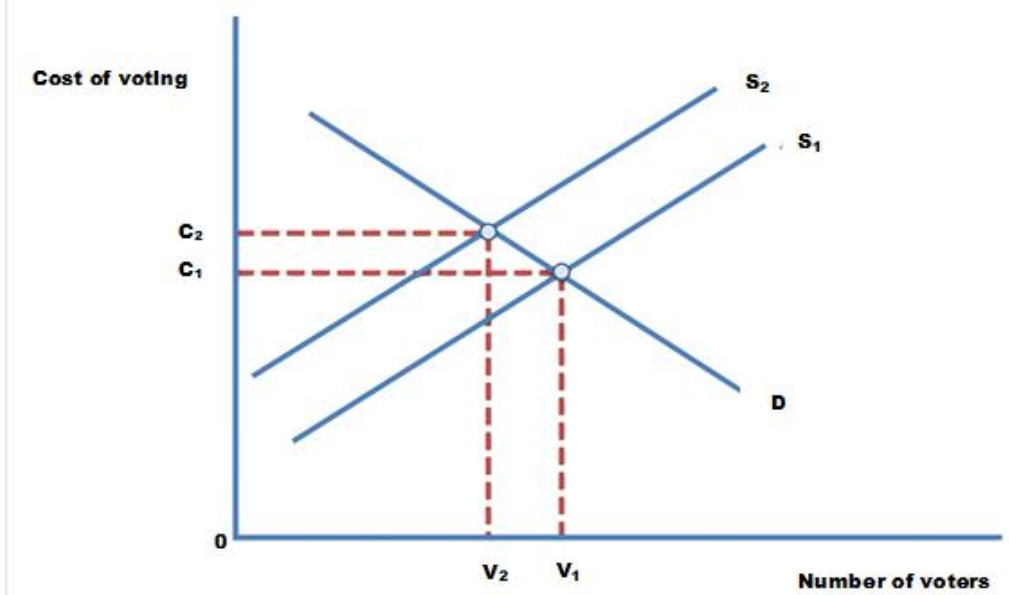

Figure 2. Illustration of the effect of a policy decision by the Electoral Commission of Ghana, arising from externally-induced challenges or external shocks, on the number of voters on polling day 


\subsection{From Neoclassical Theoretical Formulation to a Political Economy Analysis}

The decision by an individual to vote (or not to vote) in elections can be influenced by his group affiliations which could be voluntary organizations or through blood ties based on family, clan and ethnic groups. Political class elites of relatively large and powerful groups who compete for national power mobilize their people to vote for their preferred political parties. This phenomenon is related to the countervailing power hypothesis attributed to Galbraith (1952). Therefore voter turnout could be high in communities with high degree of homogeneity of large ethnic groups, whose elites engage in ethnic-based voter mobilization.

Hence Equation 3 is reformulated as a political economy model in Equation 4, with additional independent variables, as an enhancement of the neo-classical model, to include structural variables).

Voter turnout $=\mathrm{f}$ (costs of voting, per capita income, disability status, employment status, literacy level, sex, age-dependency ratio, household size, rural/urban location, religiosity, mobilization efforts of political class elites of large tribes as a proxy for competition of the two main political parties, features of citizens in the electorally-swing areas of the country, general conditions of the economy, other factors)

Equation 4

\section{Methodology}

\subsection{Introduction}

Our current study is a meso-level analysis of voter participation in presidential elections in Ghana. The 2000 and 2012 elections, among the seven conducted since 1992, are the ones that could be conveniently linked to national census data for analysis. This study is an extension of the earlier work undertaken by Anaman and Bukari (2019a). The extensions used in the current study are in the use of non-linear functional forms, different turnout ratios, and the incorporation of the cost of participation of the voter in an election, and incomes of householders, in order to estimate the price and income elasticity of demand of voting.

\subsection{Analysis of Participation in the 2012 Presidential Election}

A dependent variable used on our analysis is the turnout ratio, defined as the total votes cast divided by the total number of registered voters. As a ratio, the voter turnout has the total number of registered voters as the denominator. Scholars such as Blais et al. (2004) use alternative measures of turnout ratio, which have different variables for the denominator to denote the eligible voter population. For our study, we used two measures of the turnout ratio. The first measure was the official turnout ratio compiled by ECG for all constituencies in 2000 and 2012. The second ratio had the numerator as the actual total number of votes cast (as it is for all turnout ratios); however the denominator of this ratio was the number of people, 10 years and over. This second ratio was developed to deal with the problem of bloated registers, having many under-age citizens in these registers, partly due to the registration of minors and under-age people by the two main political parties, NDC and NPP.

Our choice of 10 years was due to the fact that it was the minimum age at which the turnout ratio for all districts was between the probability interval of zero to one, as prescribed by the laws of probability. Higher-age levels used as the denominator for calculating the turnout ratio (from 11 to 17 years) resulted in several districts exceeding the maximum possible turnout ratio of $1.0(100 \%)$. The linear version of the district-based turnout regression model for 2012 election, is indicated in Equation 5, using the two models for the turnout ratio.

$$
\begin{aligned}
& \text { VOTERTURNOUT2012 } \mathrm{i}_{\mathrm{i}} \mathrm{G}_{0}+\mathrm{G}_{1} \text { COSTOFVOTING }_{\mathrm{i}}+\mathrm{G}_{2} \text { PERCAPITAINCOME }_{\mathrm{i}}+\mathrm{G}_{3} \text { BCWSWINGREGIONS }_{\mathrm{i}}+\mathrm{G}_{4} \\
& \text { DISTRICTCAPITALCREATED2012 } 2_{\mathrm{i}}+\mathrm{G}_{5} \text { PROPASANTE }_{\mathrm{i}}+\mathrm{G}_{6} \text { PROPEWE }_{\mathrm{i}}+\mathrm{G}_{7} \text { PROPLITERATE }_{\mathrm{i}}+\mathrm{G}_{8} \\
& \text { PROPEMPLOY }_{\mathrm{i}}+\mathrm{G}_{9} \text { PROPURBAN }_{\mathrm{i}}+\mathrm{G}_{10} \text { PROPAGEDEPRATIO }_{\mathrm{i}}+\mathrm{G}_{11} \text { POP10ANDABOVE }_{\mathrm{i}}+\mathrm{G}_{12} \\
& \text { PROPMUSLIM }_{\mathrm{i}}+\mathrm{G}_{13} \text { RATIOSEX }_{\mathrm{i}}+\mathrm{G}_{14} \text { PROPELECTRICITYCON }_{\mathrm{i}}+\mathrm{G}_{15} \text { PROPWASTECOLLECTED }_{\mathrm{i}}+\mathrm{G}_{16} \\
& \text { SIZEHH }_{\mathrm{i}}+\mathrm{G}_{17} \text { PROPDISABLED }_{\mathrm{i}}+\mathrm{G}_{18} \text { SIZEHH }_{\mathrm{i}} * \text { PROPDISABLED }_{\mathrm{i}}+\mathrm{U}_{\mathrm{i}}
\end{aligned}
$$

Where VOTERTURNOUT2012 $2_{\mathbf{i}}$ is measured in two ways: (1) the official turnout ratio, and (2) defined as the total votes cast in the 2012 presidential election divided by the total number of people 10 years and over using the mid-2012 population estimate. 
COSTOFVOTING $_{\mathbf{i}}$ (PRICE) is the price to the individual for voting in a national election, proxied as the time costs related to voting on the polling day. The instrumental variable used is the land area of the district in square kilometres divided by the number of polling stations in the district used by ECG for the national election in that year. A negative impact is expected as higher time travel cost to polling stations could discourage turnout on polling day.

PERCAPITAINCOME $_{\mathbf{i}}$ is the average per capita district household expenditure derived from the 2012/2013 GLSS6 data for the district. These data were collected from October 2012 and their collection was completed in October 2013. The presidential election was held on 7 December 2012. Hence the GLSS income-related data were appropriate for our analysis. Per capita income is the average total household expenditures divided by the average adult household size, and is the preferred income measure of poverty status of Ghanaians used by the Ghana Statistical Service and international organizations such as the World Bank (Ghana Statistical Service, 2014, 2018). The impact of per capita income on voter turnout is positive given that voting is assumed to be a normal good. As indicated earlier, citizens with higher incomes might appreciate much more the vicarious use and bequest use benefits from voting

BCWSWINGREGIONS $_{\mathbf{i}}$ is a dichotomous variable assigned a value of 1 if the district is part of Brong Ahafo Region, or Central Region, or the Western Region, and zero otherwise. These three are considered to be electorally-swing regions in Ghana's Fourth Republican elections. Voter participation in an electorally-swing region could increase or decrease in an election due to national economic shocks and/or specific events affecting a region. Disillusionment with electoral politics that negatively affects participation is more likely to come from electorally-swing regions. In January 2019, the Brong Ahafo region was divided into three: Ahafo, Bono and Bono East regions, and the Western region was also divided into: West-North and Western regions.

DISTRICTCREATED2012 ${ }_{\mathbf{i}}$ is a variable that has a value of 1 if the district was created during election year 2012, and zero if otherwise. Creation of new districts during an election year is a favourite of the incumbent government to maximize its votes, as part of its accumulation of voter mobilization capital. The impact of the variable is not clear.

PROPASANTE $\mathrm{i}_{\mathrm{i}}$ is the fraction of the population who are Asantes using 2010 Census data. Based on the countervailing power hypothesis (Galbraith, 1952), we postulate that mobilization for electoral competition in Ghana is closely aligned with the two largest tribes in Ghana, Asantes and Ewes. The Asantes are the largest tribe in Ghana and vote disproportionately for the NPP, the party dominated by Asante political class elites (Anaman and Bukari, 2019a, 2019b).

PROPEWE $_{\mathrm{i}}$ is the fraction of the population who are Ewes based on the 2010 Census data . Ewes are the second largest tribe in Ghana. Ewes vote disproportionately for the NDC, the party dominated by Ewe political class elites (Anaman and Bukari, 2019a, 2019b).

PROPLITERATE $\mathrm{i}_{\mathbf{i}}$ is the fraction of the population who at least attended one year of formal schooling. We are not sure of the expected impact of this variable on voter participation; this is due to the literacy data measuring only those with at least one year of formal schooling.

PROPEMPLOY $\mathrm{Y}_{\mathrm{i}}$ is the fraction of the population employed. The effect of employment status on voter turnout appears to be uncertain and could be positive, negative or not significant. This assertion is due to the fact that employed people are mainly in the informal sector; the informal sector accounted for $86.2 \%$ of the working population in 2010 up from the 83.9\% recorded in 2000 as reported by the GSS (2013).

PROPURBAN $_{\mathrm{i}}$ measures the proportion of the population who reside in areas considered to be urban. The effect of urbanization on voter turnout rate is not clear and could be positive, negative or not significant.

AGEDEPRATIO $_{\mathrm{i}}$ is a ratio measuring the poverty burden indicated by the dependency ratio. This ratio has the numerator as the number of people less than 15 years plus the number of people above 64 years. The denominator is the number aged 15 to 64 . We expect a negative impact of increasing dependency ratio on turnout rates.

POP10ANDOVER $_{\mathrm{i}}$ indicates the number of people who are 10 years or older. This variable is also used as a denominator for calculating turnout rates. Mobilization falls with increasing population. Hence the a priori impact of this variable on turnout rate is negative.

PROPMUSLIM $_{\mathrm{i}}$ is the fraction of the population who subscribe to the Islamic Faith. The impact of this variable on voter turnout rate is not clear and could be positive, negative or not significant, given the conflicting results of various studies on the effect of religiosity on turnout rates.

RATIOSEX $\mathrm{X}_{\mathrm{i}}$ is the fraction of males to females. The impact of this variable on voter turnout rate is not clear and could be positive, negative or insignificant.

PROPELECTRICITYCON $\mathrm{N}_{\mathbf{i}}$ is the proportion of households which have connection to the national electricity grid, linked to the availability of electricity within their communities. The effect of electricity connection on voter turnout rate is not clear and could be positive, negative or not significant. 
PROPWASTECOLLECTED $i$ is the proportion of households which have their solid wastes are collected. The expected effect of household waste collection service is positive. The subscription of this service is a key characteristic of middle and upper class families in Ghana. As such this variable could measure those householders who might pay more attention to the vicarious use and bequest use values of voting, given their income and wealth status.

$\mathrm{SIZEHH}_{\mathrm{i}}$ is the number of adult members per household. This variable was derived by adjusting the household size (N) by the formula $\left(\mathrm{N}^{0.7}\right)$, a common formula used in determining adult-equivalent household size (Bellu and Liberati, 2005, pp.3-4). The directional impact of this variable on the voter turnout is not clear as different results are found in the literature.

PROPDISABLED $_{\mathrm{i}}$ is the fraction of the population considered to be disabled. The turnout rate may decline as the proportion of the population classified as disabled increases.

SIZEHH $_{\mathbf{i}} *$ PROPDISABLED $_{i}$ is an interaction term of the size of household and fraction of people disabled. This term is used to evaluate whether households with increasing numbers of disabled people have lower or higher turnout rates.

$\mathrm{U}_{\mathrm{i}}$ is the regression equation error term.

The estimation of the linear and natural logarithmic forms of the model, expressed in Equation 5, were undertaken. The double log form is indicated in Equation 6 below:

LVOTERTURNOUT2012 $_{\mathrm{i}}=\mathrm{H}_{0}+\mathrm{H}_{1}$ LCOSTOFVOTING $_{\mathrm{i}}+\mathrm{H}_{2}$ LPERCAPITAINCOME $_{\mathrm{i}}+\mathrm{H}_{3}$ BCWSWINGREGIONS $_{\mathrm{i}}+\mathrm{H}_{4}$ DISTRICTCAPITALCREATED2012 ${ }_{\mathrm{i}}+\mathrm{H}_{5}$ LPROPASANTE $_{\mathrm{i}}+\mathrm{H}_{6}$ LPROPEWE $_{\mathrm{i}}+\mathrm{H}_{7}$ LPROPLITERATE $_{\mathrm{i}}+\mathrm{H}_{8}$ LPROPEMPLOY $_{\mathrm{i}}+\mathrm{H}_{9}$ LPROPURBAN $_{\mathrm{i}}+\mathrm{H}_{10}$ LPROPAGEDEPRATIO $_{\mathrm{i}}+\mathrm{H}_{11}$ LPOP10ANDABOVE $_{\mathrm{i}}+\mathrm{H}_{12}$ LPROPMUSLIM $_{\mathrm{i}}+\mathrm{H}_{13}$ LRATIOSEX $_{\mathrm{i}}+\mathrm{H}_{14}$ LPROPELECTRICITYCON $_{\mathrm{i}}+\mathrm{H}_{15}$ LPROPWASTECOLLECTED $_{\mathrm{i}}+\mathrm{H}_{16}$ LSIZEHH $_{\mathrm{i}}+\mathrm{H}_{17}$ LPROPDISABLED $_{\mathrm{i}}+\mathrm{H}_{18}$ LSIZEHH $_{\mathrm{i}}^{*}$ LPROPDISABLED $_{\mathrm{i}}+\mathrm{W}_{\mathrm{i}}$

Equation 6

Where LCOSTOFVOTING, LPERCAPITAINCOME, LPROPASANTE, LPROPEWE, LPROPLITERATE, LPROPEMPLOY, LPROPURBAN, LPROPAGEDEPRATIO, LPOP10ANDABOVE, LPROPMUSLIM, LRATIOSEX, LPROPELECTRICITYCON, LPROPWASTECOLLECTED, LSIZEHH, LPROPDISABLED are the natural logarithmic forms of COSTOFVOTING, PERCAPITAINCOME, PROPASANTE, PROPEWE, PROPLITERATE, PROPEMPLOY, PROPURBAN, PROPAGEDEPRATIO, POP10ANDABOVE, PROPMUSLIM, RATIOSEX, PROPELECTRICITYCON, PROPWASTECOLLECTED, SIZEHH, and PROPDISABLED, respectively.

$\mathrm{W}_{\mathrm{i}}$ is the equation error term.

The choice of whether the linear or double log model was the more appropriate for analytical interpretation of the results was based on the specification test developed by Ramsey (1969). Other diagnostic tests involving homoscedasticity and multicollinearity were applied to determine the more appropriate functional forms of the models. This econometric diagnostic approach was also used to determine the suitability of the two dependent variables.

\subsection{Analysis of Participation in the 2000 Presidential Election}

The natural $\log$ specification of the voter turnout regression equation for the 2000 presidential election is indicated in Equation 7.

LVOTERTURNOUT2000 $_{\mathrm{i}}=\mathrm{J}_{0}+\mathrm{J}_{1}$ LCOSTOFVOTING $_{\mathrm{i}}+\mathrm{J}_{2}$ LPERCAPITAINCOME $_{\mathrm{i}}+\mathrm{J}_{3}$ BCWSWINGREGIONS $_{\mathrm{i}}+$ $\mathrm{J}_{4}$ LPROPASANTE $_{\mathrm{i}}+\mathrm{J}_{5}$ LPROPEWE $_{\mathrm{i}}+\mathrm{J}_{6}$ PROPLITERATE $_{\mathrm{i}}+\mathrm{J}_{7}$ LPROPEMPLOY $_{\mathrm{i}}+\mathrm{J}_{8}$ LPROPURBAN $_{\mathrm{i}}+\mathrm{J}_{9}$ LPROPAGEDEPRATIO $_{\mathrm{i}}+\mathrm{J}_{10}$ LSIZEHH $_{\mathrm{i}}+\mathrm{J}_{11}$ LPOP10ANDABOVE $_{\mathrm{i}}+\mathrm{J}_{12}$ LPROPMUSLIM $_{\mathrm{i}}+\mathrm{J}_{13}$ LRATIOSEX $_{\mathrm{i}}+\mathrm{X}_{\mathrm{i}}$ Equation 7

$\mathrm{X}_{\mathrm{i}}$ is the equation error term.

There were no disability data collected during the 2000 National Population Census and secondly, no new districts were created in 2000. This is the explanation for the absence of DISTRICTCAPITALCREATED2000 and LPROPDISABLED variables. All the 13 independent variables indicated in Equation 7 are for indicators measured in 
the year 2000 as the national population census for that year coincided with the 2000 national election. The per capita income for the 2000 election for each district was based on data from GLSS4 completed in October 1999, a year before the December 2000 election. The independent variables in the 2000 election model are less than those in the 2012 election model due to unavailability of data for several variables.

\section{Results and Discussion}

\subsection{Results for 2012 Regression Models - Introduction}

The summary results of the 2012 voter turnout regression analysis are presented in Tables 2 and 3, using the turnout rates from the official registered voters, and also based on the citizens in the district aged 10 and above. With two alternative models, based on the two dependent variables, for which one has to be selected for interpretative analysis for the derivation of policy implications, the laws of probability had to be met for the dependent variable. Further, the econometric diagnostic tests and power of the models were used for the selection of the optimal model for the 2012 election.

First, the dependent variables of both models were in the range of zero to one thus meeting the basic law of probability. Second, both models had no significant heteroscedasticity as measured by the Gleijser (1969) and the Lagrangean Multiplier (LM) tests. Third, there was no significant multicollinearity with both models, with the variance inflation factor (VIF) of all the independent variables, less than 10.0. However, the model with the dependent variable based on the official turnout rate was highly mis-specified based on the Ramsey Reset test ( $\mathrm{p}$ value of 0.001 ; refer to Table 2). The alternative model, with the dependent variable related to citizens aged 10 and over, was adequately specified based on the Ramsey Reset test (see Table 3; $\mathrm{p}$ value of 0.357 ). The latter model also had much higher $\mathrm{R}^{2}$ than the former model (based on the official turnout rate). Hence, the model with the dependent variable related to citizens aged 10 is used for interpretative discussion related to policy implications.

\subsection{Voter Turnout 2012 Regression Analysis - Discussion with the Chosen Model}

The results from the regression analysis, with the chosen model (Table 3), indicated that 14 out of the 18 independent variables were statistically significant. The cost of voting had the expected negative sign indicating that the voter turnout rate went down with increasing cost of voting. With both the dependent and independent variables, measured in natural logarithmic form, the parameter estimate for the cost of voting was an elasticity measure. Given the parameter value of -0.054 , this meant that one percent increase in the cost of voting led to a reduction in the voter turnout by $0.054 \%$. Similarly, for the per capita income, which was also a significant variable, one percent increase in per capita income led to an increase in the voter turnout by $0.108 \%$.

Using the standardized parameter estimates (refer to the results in Table 3, column 3), the cost of voting was the fourth most important independent variable affecting turnout illustrating the important role of easy access to polling stations to increased voter participation. Both the price and income elasticities of demand confirmed that voting was a normal good; further with the values both elasticities being less than one, voting could be classified as both price-inelastic and income-inelastic good. Our results are similar to that obtained by Schelker and Schneiter (2017), where 1.8\% increase in voter turnout was observed, based on the payment by the State of the pre-paid envelope cost of 0.85 dollar, used for posting completed ballot papers by eligible voters.

Now, we turn our attention to the structuralist variables that influenced the voter turnout. Increasing number of people, 10 years and above, led to decreased voter turnout due to the well-known factor of decreasing voter mobilization with increasing numbers (for example, see Gray and Caul, 2000). This was the most important independent variable affecting voter turnout based on the standardized parameter estimates, followed by the age dependency ratio. The third most important independent variable was the share of the population accounted for by Ewes. The natural logarithmic of the variable, and the square of this natural logarithmic form of the variable, were both significant but with opposing signs. Numerical simulation modelling analysis was undertaken to estimate the predicted elasticity of the turnout rate based on the proportion of Ewes, and the estimated equation, for all 216 districts. The average elasticity was 0.031 with $79 \%$ of the districts recording positive turnout increases. The minimum and maximum elasticity values were -0.048 and 0.096 .

The parameter of the Asante variable was also highly significant with the estimated elasticity of 0.030 (the parameter estimate denoted in Table 3). The overall positive influence of the Asante and Ewe variables on voter turnout showed a countervailing power struggle at work. The political class elites of the two tribes mobilized their people, through the NPP and NDC, respectively, in their struggle for power. This countervailing power struggle concept is also reported by Anaman and Bukari (2019a, 2019b). Using the standardized parameter estimates, the Ewes' overall average voter turnout was modestly stronger than that of the Asantes ( 0.315 versus 0.272$)$.

One variable that positively influenced voter turnout was the proportion of a district's households that had their solid wastes collected from their homes by private and/or public agencies. As indicated earlier, this variable could be a proxy measure of the wealth of the household. Nationally, based on 2010 Census data, only 14.4\% of Ghanaian households 
had their solid wastes collected from their homes compared to $23.8 \%, 37.7 \%$ and $9.1 \%$ of households, which used public containers, public dumps, and indiscriminate open space dumping, respectively, as their main methods of disposal of solid wastes (GSS, 2013). These householders, who have their solid wastes collected, are in the middle and upper income classes; they would appreciate the direct use and option use values of voting, and further would also place higher premiums for the vicarious use and bequest use values of voting. The other variable positively influencing voter turnout rate was household size reflecting the increasing voter mobilization resulting from increasing household size.

Several other variables influenced the voter turnout in a negative manner (refer to Table 3). The age-dependency ratio was the most important influential negative variable. Increasing dependency ratio measured increasing household care burden. As the age-dependency ratio of a district increased, the voter turnout declined. The creation of new districts in the 2012 election year actually had negative impact on voter turnout possibly due to the satisfaction of the citizens of improved development in the future for which the ruling party could have been rewarded with an increased share of the total votes cast for those new districts, but with lower numbers of people showing up to vote. An increasing sex ratio of a district (the number of males divided by the number of females) implied decreasing femininization of the district. Hence, the reduction in the voter turnout from the increasing sex ratio demonstrated the lower voter participation by males.

Increasing shares in the district population arising from urban share of the district population, and the proportion of the district population who had at least one year of formal education - both led to reduced voter turnout. This result reflected adult population with minimal education and residing in urban settlements. While increasing household size by itself led to increased voter turnout, when combined with increasing proportions of disabled people, it resulted in decreased turnout. This result could be due to disabled people within the household finding it difficult to vote due to inadequate support systems; this is similar to the result shown by Schur (2017). Finally, it was shown that voters in the three electorally-swing regions did not have significantly higher turnout rates than those from other seven regions, though the parameter estimate had negative sign.

Table 2. Summary of the results of the voter participation regression analysis using the total number of people who voted in the 2012 national presidential election divided by the total number of registered voters in the district, with variables expressed in natural logarithmic forms, except for the dummy variables.

The dependent variable is LVOTERTURNOUT2012 (based on total number of registered voters)

\begin{tabular}{|c|c|c|c|c|c|}
\hline $\begin{array}{l}\text { Independent } \\
\text { Variable }\end{array}$ & $\begin{array}{l}\text { Parameter } \\
\text { Estimate }\end{array}$ & $\begin{array}{l}\text { Standardized } \\
\text { Estimate }\end{array}$ & $\begin{array}{l}\text { Computed } \\
\text { T Value }\end{array}$ & $\begin{array}{c}\text { Significance } \\
\text { Probability } \\
\text { Level }\end{array}$ & VIF \\
\hline INTERCEPT & 4.129 & 0.000 & 3.033 & $0.003 * * *$ & 0.000 \\
\hline LCOSTOFVOTING & 0.001 & 0.014 & 0.119 & 0.906 & 3.490 \\
\hline LPERCAPITAINCOME & 0.020 & 0.123 & 1.151 & 0.251 & 2.785 \\
\hline BCWSWINGREGIONS & -0.051 & -0.247 & -2.835 & $0.005 * * *$ & 1.843 \\
\hline LDISTRICTCREATED2012 & 0.007 & 0.040 & 0.519 & 0.605 & 1.467 \\
\hline LPROPASANTE & 0.007 & 0.234 & 2.179 & $0.031 * *$ & 2.782 \\
\hline LPROPEWE & 0.009 & 0.234 & 1.715 & $0.088^{*}$ & 4.493 \\
\hline LPROPEWESQUARED & -0.006 & -0.545 & -4.081 & $0.000 * * *$ & 4.310 \\
\hline LPROPLITERATE & 0.025 & 0.118 & 0.755 & 0.451 & 5.914 \\
\hline LPROPEMPLOY & 0.036 & 0.013 & 0.117 & 0.907 & 2.925 \\
\hline LPROPURBAN & -0.002 & -0.016 & -0.164 & 0.870 & 2.192 \\
\hline LAGEDEPRATIO & 0.022 & 0.057 & 0.409 & 0.683 & 4.647 \\
\hline LREGISTEREDVOTERS & -0.011 & -0.099 & -0.892 & 0.374 & 3.008 \\
\hline LPROPMUSLIM & -0.009 & -0.137 & -1.382 & 0.169 & 2.362 \\
\hline LRATIOSEX & -0.074 & -0.085 & -0.983 & 0.327 & 1.815 \\
\hline LPROPELECTRICITYCON & 0.005 & 0.047 & 0.641 & 0.522 & 1.300 \\
\hline LPROPWASTECOLLECTED & 0.001 & 0.010 & 0.144 & 0.885 & 1.239 \\
\hline LSIZEHH & 0.112 & 0.301 & 2.434 & $0.016 * *$ & 3.703 \\
\hline LSIZEHH*LPROPDISABLED & 0.013 & 0.085 & 1.082 & 0.281 & 1.482 \\
\hline
\end{tabular}

Notes on Table 2

$\mathrm{R}^{2}=0.309 * * * \quad$ Adjusted $\mathrm{R}^{2}=0.235^{* * *} \quad$ Sample size is 216.

Probability significance level of the Ramsey Reset Test for correct model specification based

on the null hypothesis of correct model specification

$0.001 * * *$ 
Probability significance level of the Glejser test of heteroscedasticity based on the null hypothesis of homoscedasticity

0.711

Probability significance level of the LM test of heteroscedasticity based on the null hypothesis of homoscedasticity 0.950

*** denotes statistical significance of the parameter at the $1 \%$ level.

** denotes statistical significance of the parameter at the $5 \%$ level.

* denotes statistical significance of the parameter at the $10 \%$ level. 
Table 3. Summary of the results of the voter participation regression analysis using the total number of people who voted in the 2012 national presidential election divided by the total number of people, 10 years and above, in a district, with variables expressed in natural logarithmic forms, except for the dummy variables.

The dependent variable is LVOTERTURNOUT2012 (based on people 10 years and above) (CHOSEN MODEL)

\begin{tabular}{|c|c|c|c|c|c|}
\hline $\begin{array}{l}\text { Independent } \\
\text { Variable }\end{array}$ & $\begin{array}{c}\text { Parameter } \\
\text { Estimate }\end{array}$ & $\begin{array}{c}\text { Standardized } \\
\text { Estimate }\end{array}$ & $\begin{array}{c}\text { Computed T } \\
\text { Value }\end{array}$ & $\begin{array}{c}\text { Significance } \\
\text { Probability Level } \\
\end{array}$ & VIF \\
\hline INTERCEPT & 18.122 & 0.000 & 4.420 & $0.000 * * *$ & 0.000 \\
\hline LCOSTOFVOTING & -0.054 & -0.290 & -2.790 & $0.006 * * *$ & 3.466 \\
\hline LPERCAPITAINCOME & 0.108 & 0.188 & 2.050 & $0.042 * *$ & 2.708 \\
\hline BCWSWINGREGIONS & -0.015 & -0.020 & -0.273 & 0.785 & 1.799 \\
\hline LDISTRICTCREATED2012 & -0.123 & -0.213 & -3.283 & $0.001 * * *$ & 1.349 \\
\hline LPROPASANTE & 0.031 & 0.274 & 2.951 & $0.004 * * *$ & 2.776 \\
\hline LPROPEWE & 0.042 & 0.322 & 2.758 & $0.006 * * *$ & 4.395 \\
\hline LPROPEWESQUARED & -0.011 & -0.282 & -2.449 & $0.015 * *$ & 4.279 \\
\hline LPROPLITERATE & -0.176 & -0.242 & -1.794 & $0.075^{*}$ & 5.848 \\
\hline LPROPEMPLOY & -1.532 & -0.154 & -1.624 & 0.106 & 2.904 \\
\hline LPROPURBAN & -0.074 & -0.220 & -2.645 & $0.009 * * *$ & 2.231 \\
\hline LAGEDEPRATIO & -0.512 & -0.369 & -3.178 & $0.002 * * *$ & 4.339 \\
\hline LPOP10ANDABOVE & -0.285 & -0.691 & -8.716 & $0.000 * * *$ & 2.025 \\
\hline LPROPMUSLIM & 0.028 & 0.117 & 1.375 & 0.171 & 2.332 \\
\hline LRATIOSEX & -0.767 & -0.250 & -3.389 & $0.001 * * *$ & 1.757 \\
\hline LPROPELECTRICITYCON & -0.026 & -0.072 & -1.130 & 0.260 & 1.289 \\
\hline LPROPWASTECOLLECTED & 0.033 & 0.130 & 2.111 & $0.036 * *$ & 1.223 \\
\hline LSIZEHH & 0.245 & 0.189 & 1.771 & $0.078 *$ & 3.661 \\
\hline LSIZEHH*LPROPDISABLED & -0.068 & -0.126 & -1.897 & $0.060^{*}$ & 1.424 \\
\hline
\end{tabular}

\section{Notes on Table 3}

$\mathrm{R}^{2}=0.490 * * *$

Adjusted $\mathrm{R}^{2}=0.434 * * *$

Sample size is 216 .

Probability significance level of the Ramsey Reset Test for correct model specification based on the null hypothesis of correct model specification

Probability significance level of the Glejser test of heteroscedasticity based on the null hypothesis of homoscedasticity

Probability significance level of the LM test of heteroscedasticity based on the null hypothesis of homoscedasticity 0.704

*** denotes statistical significance of the parameter at the $1 \%$ level.
$* *$ denotes statistical significance of the parameter at the $5 \%$ level.
$* \quad$ denotes statistical significance of the parameter at the $10 \%$ level.

\subsection{Results for 2000 Regression Models - Introduction}

The results of the 2000 turnout regression analysis are presented in Tables 4 and 5, using the turnout rate from the official registered voters, and also the turnout rate based on the citizens in the district aged 10 and above, as the two alternative dependent variables. Both dependent variables met the statistical probability criterion that a ratio must be between zero and one. Further both models had no significant diagnostic problems related to specification and heteroscedasticity. Hence, the power of the model indicated by the $\mathrm{R}^{2}$ was used to decide the more appropriate model. The 2000 turnout model based on the official registered number of voters was superior $\left(R^{2}\right.$ of 0.346 and adjusted $R^{2}$ of 0.237), as compared to the alternative model based on the dependent variable using citizens aged 10 and over (with an $\mathrm{R}^{2}$ of 0.288 and adjusted $\mathrm{R}^{2}$ of 0.168 ). It must be noted that the high VIF figures for the two per capita income variables was due to the inclusion of the squared component. However, this had no binding effect as both variables were significant. Further all other independent variables had low VIFs. 


\subsection{Voter Turnout 2000 Regression Analysis - Discussion with the Chosen Model}

Using the appropriate regression model, based on the official turnout rate (Table 4), eight of the 14 independent variables significantly influenced the official voter turnout rate. These are (1) cost of voting, (2) per capita income, (3) the square of per capita income, (4) the dummy variable for the combined three swing regions (Brong Ahafo, Central and Western), (5) Asante tribe, (6) Ewe tribe, (7) formal educational attainment, and (8) urban proportion of the district population. The price elasticity of demand was negative, and had a value less than 1.0, indicating that voting was an price-inelastic good. The income elasticity of demand was significant with both positive and negative components, but with complete domination of the positive component. The derived turning point occurred at $402 \%$ of income, beyond the $100 \%$ income maximum data limitation. We conclude that the income elasticity of demand was positive for all practical purposes.

The three electorally-swing regions had lower voter turnout rates in 2000 compared to other regions. The parameters of the ethnicity-based variables, related to the Asantes and Ewes, were significant and positive. Based on the standardized estimates, the Asante variable was modestly stronger than the Ewe variable ( 0.457 versus 0.398$)$. The stronger Asante turnout was a factor in NPP victory in the 2000 election; this was a countervailing result to the 2012 election, won by NDC, anchored around a stronger Ewe turnout in that year. Finally, citizens in urban areas had higher voter turnouts.

Table 4. Summary of the results of the voter participation regression analysis using the total number of people who voted in the 2000 presidential election divided by the total number of registered voters in the district, with variables expressed in natural logarithmic forms, except for the dummy variables.

The dependent variable is LVOTERTURNOUT2000 (based on total number of registered voters) (CHOSEN MODEL)

\begin{tabular}{|l|c|c|c|c|c|}
\hline $\begin{array}{l}\text { Independent } \\
\text { Variable }\end{array}$ & $\begin{array}{c}\text { Parameter } \\
\text { Estimate }\end{array}$ & $\begin{array}{c}\text { Standardized } \\
\text { Estimate }\end{array}$ & $\begin{array}{c}\text { Computed T } \\
\text { Value }\end{array}$ & $\begin{array}{c}\text { Significance } \\
\text { Probability Level }\end{array}$ & VIF \\
\hline INTERCEPT & 3.894 & 0.000 & 2.453 & $0.016^{* *}$ & 0.000 \\
\hline LCOSTOFVOTING & -0.030 & -0.268 & -2.171 & $0.033^{* *}$ & 1.962 \\
\hline LPERCAPITAINCOME & 0.902 & 2.928 & 1.683 & $0.096^{*}$ & 388.564 \\
\hline LPERCAPITAINCOMESQ & -0.112 & -3.094 & -1.786 & $0.078^{*}$ & 385.792 \\
\hline BCWSWINGREGIONS & -0.126 & -0.353 & -2.659 & $0.009^{* * *}$ & 2.260 \\
\hline LPROPASANTE & 0.028 & 0.457 & 3.029 & $0.003^{* * *}$ & 2.920 \\
\hline LPROPEWE & 0.028 & 0.398 & 3.117 & $0.003^{* * *}$ & 2.100 \\
\hline LPROPLITERATE & -0.138 & -0.548 & -2.830 & $0.006^{* * *}$ & 4.818 \\
\hline LPROPEMPLOY & -0.101 & -0.139 & -1.150 & 0.253 & 1.871 \\
\hline LPROPURBAN & 0.049 & 0.295 & 2.348 & $0.021^{* *}$ & 2.031 \\
\hline LAGEDEPRATIO & 0.122 & 0.153 & 1.010 & 0.315 & 2.947 \\
\hline LSIZEHH & -0.030 & -0.052 & -.414 & 0.680 & 2.061 \\
\hline LREGISTEREDVOTERS & -0.033 & -0.174 & -1.429 & 0.157 & 1.902 \\
\hline LPROPMUSLIM & -0.005 & -0.038 & -.263 & 0.793 & 2.751 \\
\hline LRATIOSEX & -0.236 & -0.142 & -1.055 & & 0.295 \\
\hline
\end{tabular}

\section{Notes on Table 4}
$\mathrm{R}^{2}=0.346^{* * * *}$
Adjusted $\mathrm{R}^{2}=0.237 * * *$
Sample size is 110 .

Probability significance level of the Ramsey Reset Test for correct model specification based

based on the null hypothesis of correct model specification

0.117

Probability significance level of the Glejser test of heteroscedasticity based on the null hypothesis

of homoscedasticity

0.710

Probability significance level of the LM test of heteroscedasticity based on the null hypothesis

of homoscedasticity

*** denotes statistical significance of the parameter at the $1 \%$ level.

** denotes statistical significance of the parameter at the $5 \%$ level.

* denotes statistical significance of the parameter at the $10 \%$ level. 
Table 5. Summary of the results of the voter participation regression analysis using the total number of people who voted in the 2000 national presidential election divided by the total number of people, 10 years and above, in a district, with variables expressed in natural logarithmic forms, except for the dummy variables.

The dependent variable is LVOTERTURNOUT2000 (based on people 10 years and above)

\begin{tabular}{|l|c|c|c|c|c|}
\hline $\begin{array}{l}\text { Independent } \\
\text { Variable }\end{array}$ & $\begin{array}{c}\text { Parameter } \\
\text { Estimate }\end{array}$ & $\begin{array}{c}\text { Standardized } \\
\text { Estimate }\end{array}$ & $\begin{array}{c}\text { Computed T } \\
\text { Value }\end{array}$ & $\begin{array}{c}\text { Significance } \\
\text { Probability } \\
\text { Level }\end{array}$ & \begin{tabular}{c} 
VIF \\
\hline INTERCEPT
\end{tabular} \\
\hline LCOSTOFVOTING & -0.391 & 0.000 & 1.254 & 0.213 & 0.000 \\
\hline LPERCAPITAINCOME & 0.682 & -0.198 & -1.530 & 0.130 & 1.960 \\
\hline LPERCAPITAINCOMESQ & -0.087 & -0.725 & 0.394 & 0.694 & 393.686 \\
\hline BCWSWINGREGIONS & -0.109 & -0.100 & -0.430 & 0.668 & 391.120 \\
\hline LPROPASANTE & 0.062 & 0.332 & -0.709 & 0.480 & 2.322 \\
\hline LPROPEWE & -0.022 & -0.103 & -0.758 & 0.451 & 2.074 \\
\hline LPROPLITERATE & -0.057 & -0.074 & -0.360 & 0.720 & 4.921 \\
\hline LPROPEMPLOY & 0.470 & 0.202 & 1.563 & 0.122 & 1.952 \\
\hline LPROPURBAN & 0.142 & 0.277 & 2.141 & $0.035^{* *}$ & 1.950 \\
\hline LAGEDEPRATIO & -0.491 & -0.202 & -1.296 & 0.198 & 2.819 \\
\hline LSIZEHH & 0.071 & 0.041 & 0.306 & 0.760 & 2.056 \\
\hline LPOP1OANDABOVE & -0.204 & -0.301 & -2.572 & $0.012^{* *}$ & 1.598 \\
\hline LPROPMUSLIM & 0.036 & 0.085 & 0.558 & 0.578 & 2.722 \\
\hline LRATIOSEX & -0.681 & -0.134 & -0.955 & 0.342 & 2.310 \\
\hline
\end{tabular}

\section{Notes on Table 5}
$\mathrm{R}^{2}=0.288 * * *$
Adjusted $\mathrm{R}^{2}=0.168 * * *$
Sample size is 110 .

Probability significance level of the Ramsey Reset Test for correct model specification based on the on the null hypothesis of correct model specification

0.443

Probability significance level of the Glejser test of heteroscedasticity based on the null hypothesis of homoscedasticity

Probability significance level of the LM test of heteroscedasticity based on the null hypothesis of homoscedasticity

\footnotetext{
*** denotes statistical significance of the parameter at the $1 \%$ level.

** denotes statistical significance of the parameter at the 5\% level.

* denotes statistical significance of the parameter at the $10 \%$ level.
}

\section{Conclusions and Policy Recommendations}

\subsection{Conclusions}

An analysis of voter turnout rates in Ghana's Fourth Republican era was conducted in this study. We showed that voting was a normal good based on the derived inelastic price and income elasticities of demand for this service provided by the State. We also estimated the elasticity of voting for citizens belonging to the two largest tribes in Ghana, Asantes and Ewes, and established that the elasticity of demand for voting was both positive and inelastic for both groups. Districts, with greater proportions of households subscribing to home-based solid wastes collection services had much higher voter turnout rates reflecting the voting behaviour of more affluent citizens. These people placed higher premiums on voting, possibly for the individual benefits related to vicarious use and bequest use values.

The cost of voting negatively influenced turnout, consistent with the neoclassical economics theory of demand, of increasing access cost reducing demand for a product. Other significant negative factors influencing voter turnout rates included increasing male/female sex ratio (gender), increasing age-based dependency ratio (poverty burden), and households with people with disabilities. The effect of urbanization on voter turnout was mixed. We also established that the voter turnout rates of male citizens were lower than those of female citizens. 
Our current study provided one more piece of evidence to support the hypothesis of countervailing power struggle between Asante and Ewe political class elites in the Fourth Republican era. The evidence from this study is based on the countervailing voter turnouts of these two largest tribes in Ghana, reported in Tables 3 and 4 . The voter turnout results reported in this study are an improved version of those reported by Anaman and Bukari (2019a). The latter study was based on only structuralist variables, while this study used both structuralist and neoclassical economics variables. The voter-choice countervailing behaviour of Asantes and Ewes is reported by Anaman and Bukari (2019a), using (1) cross-sectional regression analysis, and (2) simulation modelling analysis of voting patterns in the strongholds, of the two groups, in Ashanti and Volta regions.

\subsection{Policy Recommendations}

A review of the international literature, dealing with 2,600 years of recorded practice of democracy, since its first emergence in the City-State of Athens in Greece, in 594 BC, indicates that the inability of individuals to vote in mass elections, is related to five core issues of social exclusion, marginalization, and victimization of some citizens in a nation-state. These are (1) discrimination, based on factors such as ethnicity, gender, minority status, religion, and slavery, (2) geography, linked to poor infrastructure, (3) low quality of democracy, as it is in Ghana, where citizens are not allowed to elect their Mayors and Chief Executives in the 260 Cities and Districts, with these leaders imposed on local people by an Emperor-type National President, (4) socio-economic status, such as income and disability, and (5) natural and artificial hazards, for example, areas affected by heavy rainfall on polling days, or areas affected by communal conflicts or wars.

In this study, we established that voter turnouts in Ghana were significantly lower for citizens facing participation-reducing constraints, such as disabilities, low incomes, poverty burden, and high travel costs related to long distances to polling stations. Therefore, Ghanaian State institutions have major roles to play to correct these "market failures" dealing with low individual voter participation to ensure that the voices of all citizens are fully heard in national elections, especially in presidential elections, given the enormous powers of the National President.

Hence, we suggest that the ECG increases the number of polling stations, to reflect the increasing numbers of voters, arising from the high $2.5 \%$ annual population growth, to allow the disabled, and other disadvantaged people, including those living in remote areas, to exercise their rights to vote. The National Commission for Civic Education needs to expand its programmes to encourage citizens to vote. Finally, national security agencies should make more efforts to reduce electoral intimidation and violence, used by political parties and their agents, which prevent citizens, such as migrants, and those unable to speak the local language, especially in rural areas, from exercising their rights to vote.

\section{References}

Amenumey, D. E. K. (1968). The extension of British rule into Anlo (South-east Ghana), 1850-1890. The Journal of African History, 9(1), 99-117. https://doi.org/10.1017/S0021853700008379

Anaman, K. A. (2016). Impact of democratic political transition on the economy of Ghana, in Ninsin, K. A. (ed.), Issues in Ghana's Electoral Politics, Dakar, Senegal: Council for the Development of Social Science Research in Africa, 135-152.

Anaman, K. A. (2018). Economic Shocks and Growth in Post-Independence Ghana, 1957 to 2017. Accra: Institute for Fiscal Studies.

Anaman, K. A., \& Agyei-Sasu, F. (2014). The economic value of the environmental capital inputs used to produce gross domestic product in Ghana, 1993 to 2012. Research in World Economy, 5(2), 74-92. https://doi.org/10.5430/rwe.v5n2p74

Anaman, K. A., \& Bukari, G. A. (2019a). Political economy analysis of the voter turnout and choices in national elections during the Ghana's fourth republican era, 1992 to 2016. Research in World Economy, 10, 174-198. https://doi.org/10.11114/aef.v6i3.4202

Anaman, K. A. and Bukari, G.A. (2019b). Political economy analysis of the macroeconomic impact of national elections in Ghana during the fourth republican era, 1992 to 2016, Applied Economics and Finance, 6, 28-44.

Bachrach, P. (1967). The Theory of Democratic Elitism: A Critique. Boston: Brown.

Bank of Ghana. (2020). Monetary Policy Committee Report, 28 September. Accra: Bank of Ghana.

Bellu, L. G., \& Liberati, P. (2005). Equivalence Scales Subjective Methods. Rome: Food and Agriculture Organization.

Blais, A., Gidengil, E., Nevitte, N., \& Nadeau, R. (2004). Where does turnout decline come from? European Journal of Political Research, 43(2), 221-236. https://doi.org/10.1111/j.1475-6765.2004.00152.x

Bukari, G. A. (2017). Political Economy Analysis of Elections in Ghana's Fourth Republic (1992 to 2016). Accra: University of Ghana. 
Centre for American Women and Politics. (2019). Gender Differences in Voter Turnout. Rutgers, New Jersey, United States: Rutgers University.

Davidson, B. (1972). History of Africa. London: Spring Books.

Downs, A. (1957). An Economic Theory of Democracy. New York: Harper and Row.

Electoral Commission of Ghana. (2020). Comparative Analysis of the 2020 and 2016 Registers. Retrieved September 30, 2020, from https://ec.gov.gh/registration/2020-voter-registration-statistics.

Electoral Commission of Ghana. Results of the 2000 and 2012 National Presidential Elections. Retrieved from http://www.ec.gov.gh

Ellis, A. B. (1894). A History of the Gold Coast of West Africa. London: Chapman and Hall.

Galbraith, J. K. (1952). American Capitalism: The Concept of Countervailing Power. Boston: Houghton Mifflin.

Geys, B. (2006). Rational theories of voter turnout: a review, Political Studies Review, 4, 16-35. https://doi.org/10.1111/j.1478-9299.2006.00034.x

Ghana Statistical Service (GSS). (2008). Ghana Living Standards Survey (GLSS) Round 5 Report. Accra: GSS.

Ghana Statistical Service (GSS). (2013). 2010 National Population and Housing Census: Analytical Report. Accra: GSS.

Ghana Statistical Service (GSS). (2014). Ghana Living Standards Survey Round 6 (GLSS) 6 Main Report. Accra: GSS.

Ghana Statistical Service (GSS). (2017). Ghana Living Standards Survey Round 7 (GLSS) 7 Final Manual. Accra: GSS.

Ghana Statistical Service (GSS). (2018). Ghana Living Standards Survey Round 7 (GLSS) 7 Poverty Trends in Ghana 2005-2017. Accra: GSS.

Ghana Statistical Service (GSS). (2020). Rebased 2013-2019 Annual Gross Domestic Product April 2020 Edition. Accra: GSS.

Glejser, H. (1969). A new test for heteroscedasticity. Journal of the American Statistical Association, 64, 316-323. https://doi.org/10.1080/01621459.1969.10500976

Government of Ghana. (2020). Mid-year Budget Review and Supplementary Estimates for the Financial Year. Presented to Parliament by the Minister of Finance (MOF), 23 July. Accra: Ministry of Finance.

Gray, M., \& Caul, M. (2000). Declining voter turnout in advanced industrial democracies, 1950 to 1997 the effects of declining group mobilization. Comparative Political Studies, 33(9), 1091-1122. https://doi.org/10.1177/0010414000033009001

Hayden, G. M. (2010). The unexpected power of withholding your vote. Connecticut Law Review, 585. Retrieved from https://scholarlycommons.law.hofstra.edu/faculty_scholarship/560

Institute for Fiscal Studies (IFS). (2020). IFS Assessment of Government's Fiscal Policy Amidst COVID-19. Delivered at a Press Conference in Accra by Dr. Said Boakye, August 6.

International Institute for Democracy and Electoral Assistance (IDEA) (2006). Engaging the Electorate: Initiatives to Promote Voter Turnout from Around the World. Stockholm: IDEA.

Lacy, D., \& Christenson, D. P. (2016). Who votes for the future? Information, expectations, and endogeneity in economic voting. Political Behaviour. https://doi.org/10.1007/s11109-016-9359-3

Mares, I., \& Zhu, B. (2015). The production of electoral intimidation: economic and political incentives. Comparative Politics, 48(1), 23-41. https://doi.org/10.5129/001041515816075204

McAllister, I. (1992). Political Behaviour. London: Longman Cheshire.

Muller, D. (2014). Essays in the Political Economy of Voting and Reforms. PhD Thesis, School of Economics and Finance, Queensland University of Technology, Brisbane, Australia.

Norris, P. (2002). Democratic Phoenix. New York: Cambridge University. https://doi.org/10.1017/CBO9780511610073

Nwankwo, C. F. (2018). Vote buying in the 2018 governorship election in Ekiti State, Nigeria. Open Political Science, 1(1), 93-97. https://doi.org/10.1515/openps-2018-0005

Ramsey, J. S. (1969). Tests for specification errors in classical linear least squares regression. Journal of the Royal Statistical Society, Series B, 350-371. https://doi.org/10.1111/j.2517-6161.1969.tb00796.x

Riker, W. H., \& Ordeshook, P. (1968). A theory of calculus of voting. The American Political Science Review, 62(1), 25-42. https://doi.org/10.1017/S000305540011562X 
Rosenstone, S., \& Hansen, J. (1996). Mobilization, Participation and Democracy in America. New York: Longman.

Schelker, M., \& Schneiter, M. (2017). The Elasticity of Voter Turnout: Investing 85 cents per Voter to Increase Voter Turnout by 4 Percent. CESIFO Working Paper Number 5617. Munich: Ludwig-Maximilians University's Centre for Economic Studies and the Ifo Institute. https://doi.org/10.1016/j.electstud.2017.07.005

Schur, L. (2017). Disability, Voter Turnout, and Polling Place Accessibility. Presentation to the National Academies of Science, Engineering, Medicine's Committee on the Future of Voting (12-13 June). Rutgers, New Jersey, United States: Rutgers University.

Settle, R. F., \& Abrams, B. A. (1976). The determinants of voter participation: a more general model. Public Choice, 27, 81-89. https://doi.org/10.1007/BF01718949

Silver, M. (1973). Demand analysis of voting costs and voting participation. Social Science Research, 2, 111-124. https://doi.org/10.1016/0049-089X(73)90014-8

Solijonov, A. (2016). Voting Turnout Trends Around the World. Stockholm, Sweden: International Institute for Democracy and Electoral Assistance.

Vicente, P. (2014). Is vote buying effective? evidence from a field experiment in West Africa. Economic Journal, 124, F356-F387. https://doi.org/10.1111/ecoj.12086

\section{ENDNOTES}

Note 1: The process for creating new districts in Ghana is supposed to use two main criteria: minimum population of 75,000 (weight of 90\%) and land size (10\%). In 2004, 2008 and 2012, 73 districts were created which had (2010 Census) population sizes less than 75,000, ranging from 20,282 to 72,810, with some created without constituencies. In both 2004 and 2008, 16 new districts were created mainly in areas resided by members of big tribes whose 2010 Census population figures were less than 75,000, with two having 2010 population sizes of 28,535 and 36,514. However, several areas inhabited by small tribes, with populations greater than 75,000 , were denied district status, despite numerous appeals, from local chiefs and people, throughout the Fourth Republican era, from 1993 to 2020. Some of these areas were already districts or constituencies in the First Republican era. An example is Agona Nyakrom and its seven additional constituent towns, in the Central Region (from the small Agona tribe), with population over 85,000, a major cocoa growing area for over 100 years, had been consistently denied constituency/district status, even though it was a constituency in 1964.

Note 2: Based on GLSS data, the overall average poverty rate in Ghana decreased slightly from $24.2 \%$ in 2013 to $23.4 \%$ in 2017. The average poverty rate of the nine big tribes decreased from $15.6 \%$ in 2013 to $11.1 \%$ in 2017 ; however, the average poverty rate of the 80 small tribes increased from $36.1 \%$ in 2013 to $39.1 \%$ in 2017 . Overall, the economic growth since 1993 has been environmentally destructive, exemplified by the severe pollution of once-pristine rivers such as Densu and Pra, through mining activities, and dumping of wastes. Economic growth has also been skewed with national income shifting more to owners of human-made capital rather than labour. Finally, our research on poverty using GLSS data, suggests that growth has been poverty-increasing for many small tribes, partly explaining the recurrences of many localized conflicts across Ghana, underlined by tensions between indigenes and migrants. Indigenes, often marginalized by the State, in terms of provision of public services, sometimes use migrants as scapegoats for their problems.

Note 3: Over 50 hospitals and clinics, and dozens of new senior secondary schools, in various stages of completion, built by the previous government with foreign loans, from 2013 to 2016, were abandoned when the new government took power in January 2017. Several ultra-modern public hospitals completed in 2016, worth over 300 million US dollars, including the Bank Hospital, remained unused until the coronavirus Covid-19 pandemic reached Ghana in March 2020. Incidentally, several prominent government officials, including the Ministers of Health and Education, who contracted the coronavirus infection, were treated at these modern public hospitals in 2020.

\section{Copyrights}

Copyright for this article is retained by the author(s), with first publication rights granted to the journal.

This is an open-access article distributed under the terms and conditions of the Creative Commons Attribution license which permits unrestricted use, distribution, and reproduction in any medium, provided the original work is properly cited. 